\title{
6.11 Методика професійного навчання та економічна дидактика: тактика і стратегія формування професійної компетентності педагогів професійного навчання/фахівців з економіки
}

Швидкість сучасного життя та зміни, що відбуваються у світі, обумовлюють постійну потребу суспільства у нових, актуальних знаннях, а також сучасних вміннях i навичках. Їх набуття можна пришвидшувати, якщо ефективно функціонує освітній простір, основу якого утворюють професійні педагоги, що здатні адекватно реагувати на світові виклики (наприклад, світова пандемія обумовила миттєве впровадження різних платформ дистанційного навчання, додаткових сервісів, і хоча до цього вони й використовувалися, але більше, як додатковий інструмент) та забезпечити підготовку фахівців, які б успішно реалізовували завдання своїх роботодавців у відповідних галузях. Успіх у професії має прямий зв'язок із професійною компетентністю особистості, але, крім професійних знань, умінь та навичок, важливими $є$ й особистісні риси, що $€$ компонентами соціальної компетентності. Отже, стратегічним завданням педагогів $є$ визначення компонентів професійної та соціальної компетентностей та їх узгодження із запитами роботодавців щодо умінь і навичок майбутніх працівників.

Подібні запити репрезентуються на Всесвітньому економічному форумі у Давосі кожні п’ять роки на середньострокову перспективу. Дані щодо ТОП-10 ключових навичок сучасної успішної особистості, які б забезпечували ефективність іiі професійної діяльності, виокремлені у 2010, 2015, 2020 роках [468], відображені на малюнку 1: 
Top 10 skills

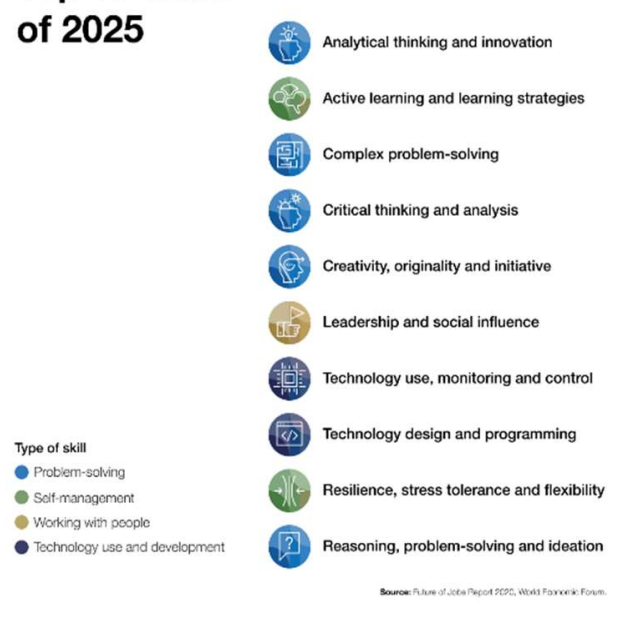

Top 10 skills
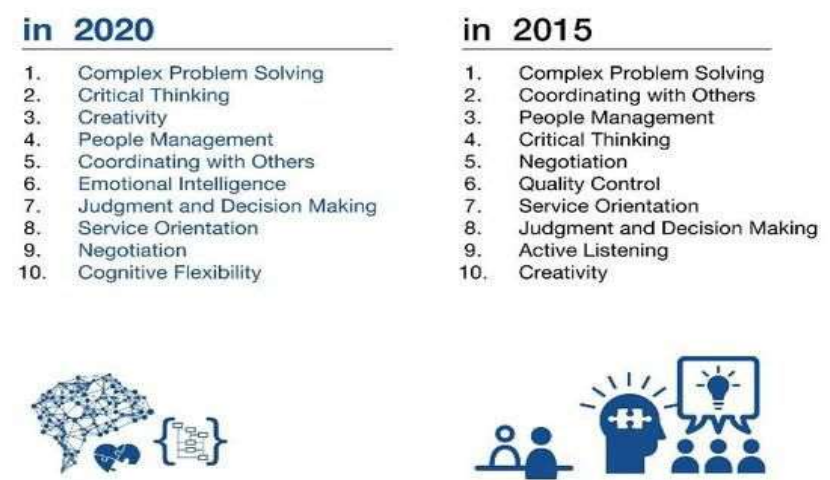

Малюнок 1. Порівняння ТОП-10 професійних навичок майбутнього у 2015, 2020 та 2025 роках

Порівнявши останні дані із навичками на 2015-2020 роки, бачимо, що відбулися суттєві зміни як змістовні, так й навіть у формі подачі та застосованій інфографіці:

1. вперше за 15 років серед пріоритетних навичок з’явилася здатність до активного навчання та використання стратегій навчання, що є позитивним сигналом для освітньої галузі в цілому, 3 одного боку, але й додатковою відповідальністю для педагогів, з іншого, оскільки вони мають імплементувати необхідні методи і прийоми, що спонукають до формування самоосвітніх навичок, у відповідні освітньо-професійні програми та конкретні навчальні дисципліни;

2. д додалися технологічні навички в аспектах їх використання у житті, a також й професійному напрямі (програмування), що обумовлено, у першу чергу, карантинними обмеженнями, спричиненими пандемією Covid-19, та необхідністю виконувати професійні обов’ язки у віддаленому доступі; крім того, це також вимагатиме зміни відповідного характеру у навчальних планах підготовки фахівців та набуття додаткових компетентностей педагогами; 
3. емоційний інтелект, що з'явився у ключових навичках 2020, наступного форуму замінений на витривалість, стресостійкість та гнучкість, які підкріплені лідерськими навичками та навичками соціального впливу; отож, у найближчій перспективі важливішими для будови успішної кар'єри замість вміння працювати у команді, співчувати, комунікувати, знову стануть індивідуальні психологічні характеристики особистості, пов'язані із працездатністю, особистою відповідальністю та вмінням швидко адаптуватися;

4. привалюючими навичками майбутнього (п'ять із десяти), як і у попередніх роках, залишаються навички щодо вирішення проблем, які пов'язані із специфікою мислення особистості, його рисами та характеристиками, що, в свою чергу, підтверджує актуальність дослідження; особисто авторка стовідсотково підтримує дану думку та активно впроваджує у власну викладацьку діяльність (про це мова буде йти згодом).

Думку учасників Всесвітнього економічного форуму підкріплюють дослідження експертів швейцарського банку UBS і консалтингової компанії PwC, які в доповіді Billionaires insights 2019 звернули увагу на те, що акції компаній, на чолі яких стоять мільярдери, ростуть майже вдвічі швидше за ринок в середньому, та пов'язали цю ситуацію з «ефектом мільярдера», появу якого автори доповіді пояснили трьома рисами характеру, властивими найбагатшим людям [469]:

$\checkmark \quad$ схильність приймати «розумні ризиковані рішення». «Коли мова заходить про те, щоб іти на ризики, підприємці-мільярдери проявляють оптимізм і фокусуються на ризиках, знаходячи розумні шляхи їх зниження», - зазначають дослідники.

зосередженість на бізнесі. Мільярдери постійно шукають навколо нові можливості.

висока стійкість, що зберігається мільярдерами, незважаючи на невдачі та перешкоди. 
У 2019-2021 рр. були проведені подібні дослідження щодо визначення ключових навичок успішного фахівця із відповідної спеціальності серед здобувачів освіти ДВНЗ «Київський національний економічний університет імені Вадима Гетьмана». Всього приймало участь 253 особи, які були об'єднані у три групи з врахуванням спеціальностей економічного, психологічного та подвійного педагогічно-економічного спрямування. На думку здобувачівмайбутніх економістів I-II курсів факультетів маркетингу та управління персоналом, соціології та психології 2020/2021 навчального року, критичне мислення $є$ найголовнішою навичкою для успішного фахівця економічного профілю (32,8\% опитаних); наступні дві якості (по 19\%) були готовність до ризику та стресостійкість; далі розташувалися цілеспрямованість (15\%), креативність (8,6\%), комунікабельність $(3,4 \%)$, наполегливість $(1,7 \%)$, інші.

Серед ключових навичок майбутнього успішного фахівця, на думку здобувачів освітньо-професійної програми «Економічна та соціальна психологія» 2019/2020 н.р., є, як і у попередньому випадку, критичність мислення (22\% опитаних), а далі розташувалися креативність (18\%), цілеспрямованість (15\%), комунікативність (15\%), наполегливість (10\%), стресостійкість (9\%), готовність до ризику (9\%), інші. Здобувачі наступного 2020/2021 навчального року цієї ж спеціальності виявилися не на стільки одностайними, запропонували нові навички та дещо змінили пріоритети: креативність (18\%), аналітичність (16\%), комунікативність (14\%), цілеспрямованість (11\%), готовність до ризику (9\%), стресостійкість (8\%), гнучкість (6\%), критичність (6\%), інноваційність (6\%), інші.

Опитування здобувачів освіти, що навчаються на спеціальності «Економічна та бізнес-освіта», а також тих, що отримують додатково педагогічну кваліфікацію, дало наступні результати: критичне мислення (24\%), комунікабельість (23\%), стресостійкість та готовність до ризику (по 15\%), стратегічність мислення (11\%), аналітичність (10\%), інші: серед яких були названі гнучкість, інноваційність, самомотивація, лідерські якості, організаційні якості, готовність до співпраці. 
Отже, думки здобувачів освіти цілком збігаються із експертними оцінками навичок майбутнього, основними з яких визнані певні характеристики мислення (більше 40\% незалежно від обраної освітньо-професійної програми). Слід зауважити, що здобувачі, які обрали фах економічного психолога, включили більш широкий перелік особистісних якостей. У випадку здобувачівекономістів, пріоритетність компонентів особистісного потенціалу підприємницької діяльності повністю співпадає з рисами «ефекту мільярдера». А здобувачам, що обрали подвійну спеціальність: педагог професійного навчання/фахівець 3 економіки, - вдалося гармонійно поєднати думки попередніх двох виділених груп опитуваних. Таким чином, ми отримали підтвердження, що підготовка фахівців економічного та міжпредметного (педагогічно-економічного, психолого-економічного) спрямувань повинна обов'язково формувати у процесі навчання характеристики економічного мислення, такі як креативність, критичність, аналітичність, прогностичність, інноваційність; та мотивувати до їх розвитку.

Наступим стратегічним завданням у системі підготовки фахівців $\epsilon$ визначення та апробація методів, прийомів та засобів, які дозволяли б сформувати протягом навчання у здобувачів освіти необхідні компоненти професійної та соціальної компетентностей, а також стимулювали б їх розвиток протягом всього життя. I це тісно пов'язано з третім стратегічним завдання, а саме: забезпечити ефективність процесу навчання дисциплінам, що входять до навчального плану підготовки фахівців певної спеціальності.

Визначені стратегічні завдання ми вирішуємо в процесі викладання навчальних дисциплін «Методика професійного навчання» для здобувачів освітньо-професійної програми «Економічна та бізнес-освіта» та «Економічна дидактика» для тих саме здобувачів, а також для тих, які обирають педагогічну кваліфікацію додатково.

В першу чергу, ми виходимо з того, що економічне мислення є різновидом професійного для здобувачів, що навчаються в економічному ВНЗ; по-друге, економічне мислення - це процес (і ми в цьому питанні згодні з когнітивними 
психологами), тому його можна вдосконалювати, тобто змінювати у напрямку підвищення продуктивності та ефективності мислення. 3 цією метою були обгрунтовані характеристики економічного мислення [470, с. 183], що співпадають в цілому із суспільною думкою:

$\checkmark$ аналітичність та наукова обтрунтованість - здатність до глибокого аналізу, точних узагальнень і висновків, критичних оцінок та ефективних рішень; дана риса наділяє людину баченням складного світу суспільного виробництва, дає змогу осягнути закони його розвитку $i$ механізми функціонування, основні зв'язки і залежності в економіці;

$\checkmark$ cистемність - забезпечення комплексного багатокомпонентного i багатоваріативного підходу до вирішення економічних проблем;

$\checkmark$ конструктивність - спрямованість на вирішення економічних завдань та забезпечення реальних і високих результатів економічної діяльності;

$\checkmark$ прогностичність - здатність передбачати наслідки прийнятих рішень у різних сферах суспільного життя, що забезпечується міжпредметним підходом до вирішення економічних ситуацій ;

$\checkmark$ зваженість - уміння дієво й результативно застосовувати теоретичні положення на практиці, правильно оцінювати, в тому числі критично, різноманітні економічні ситуації, можливі втрати та користь; і вчасно приймати необхідні всебічно обгрунтовані рішення;

$\checkmark$ діловитість - здатність енергійно та ефективно вирішувати проблеми, що виникають; уміння практично організувати певну справу, прагнення сумлінно виконувати свої обов'язки, доводити прийняті рішення до повного втілення у життя;

$\checkmark$ креативність - здатність генерувати нестандартні ідеї, бачити альтернативи, враховувати несподівані обставини, нові явища і процеси, зумовлені динамічністю економіки, НТП , рухливістю структури виробництва i потреб суспільства;

$\checkmark$ інноваційність - здатність втілювати нові оригінальні рішення у практику професійної діяльності. 
Розвиток зазначених вище характеристик може відбуватися на основі впливу на ментальні здібності особистості, що притаманні як правій, та і лівій півкулям головного мозку. Даний висновок зроблено на основі визначених специфічних можливостей півкуль головного мозку Р. Сперрі, а також дослідження Т. та Б. Бьюзен [471, с. 33-34, 520], Д. Халперн [472, с. 35] про модальність мислення. Саме тому, на початку навчання проводиться дослідження модальності мислення здобувачів за допомогою експрес-методики $[473$, с. 20$]$ та анкети Елвіна.

У 2020/2021 навчальному році у дослідженні брали участь 232 особи і були отримані наступні результати: традиційно за експрес-методикою ми отримали лівопівкульну домінантність, тобто привалювання логічного типу мислення (47,8\% опитаних), правопівкульна та збалансована модальність зустрічалися майже в однаковій кількості (25,1\% та 27,1\% відповідно). Як і в попередньому році [474, с. 111], більш грунтовне дослідження з використанням анкети Елвіна дало протилежні результати: домінуючими виявилися ментальні навички правої півкулі, тобто творчий тип мислення (48,8\% опитаних), домінування логічного типу мислення зафіксовано у 19,2\% здобувачів, та збалансована модальність зустрілася у $32,0 \%$ опитаних.

Порівняння результатів цього навчального року із даними попередніх років (див. малюнок 2) дає можливість стверджувати, що до системи економічної освіти (зокрема, до економічного університету, і це $є$ справедливим як для спеціальностей суто економічного профілю, так і психолого-педагогічного) вступають все більше здобувачів із домінантним творчим типом мислення, які добре вміють використовувати ментальні навички правої півкулі головного мозку. Таку динаміку можна пояснити, в першу чергу, заміною у КНЕУ в останні роки вступного випробування з математики історією, тобто більш гуманітарною спрямованістю абітурієнтів; та, до-друге, наслідками змін у шкільній підготовці майбутніх студентів, що обумовлені встановленим державою пріоритетом виховання всебічно розвиненої творчої особистості (до речі, цей тренд триває і в новій українській школі, але на базі компетентностей). 


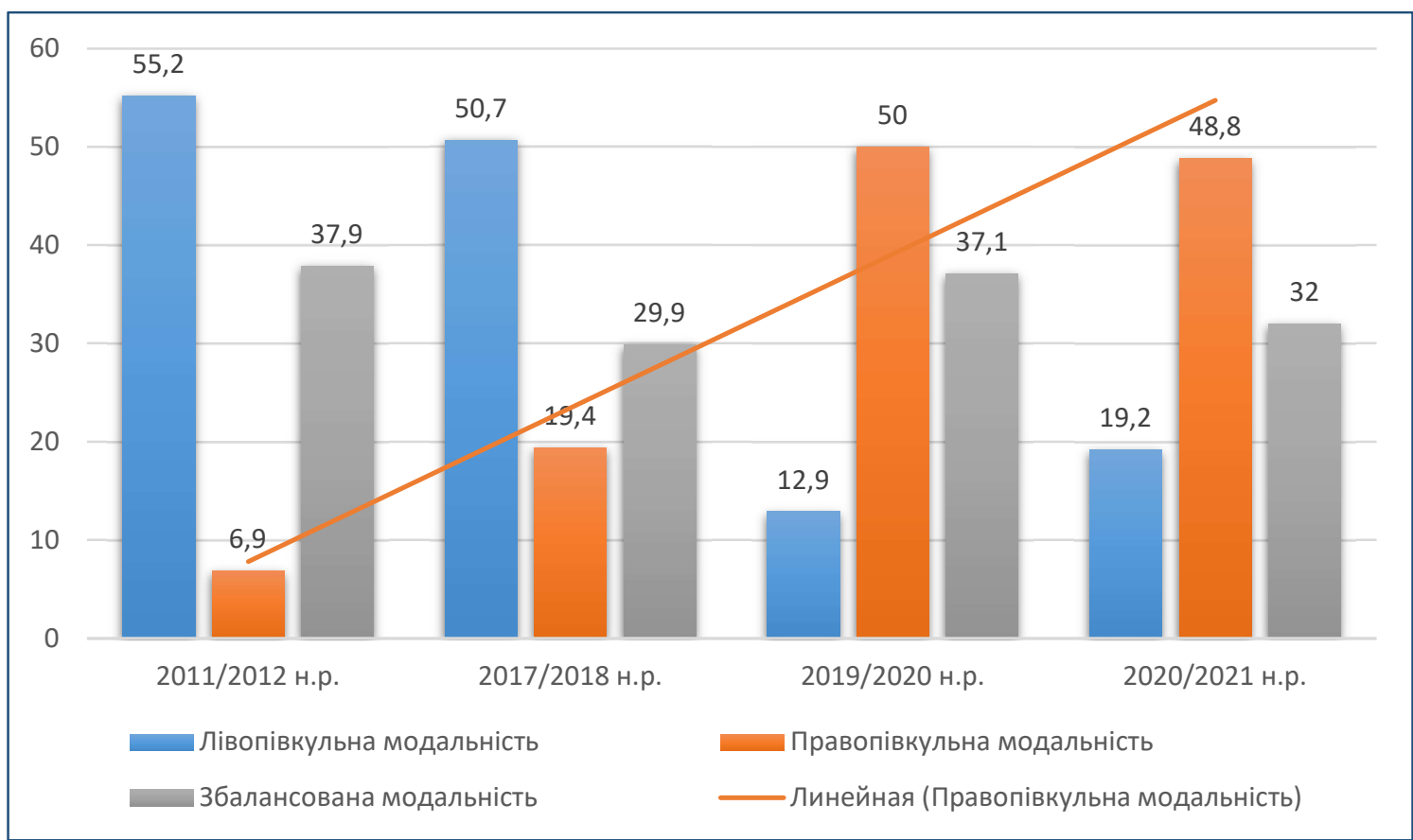

Малюнок 2. Порівняння результатів дослідження модальності мислення здобувачів освіти ДВНЗ «Київський національний економічний університет імені Вадима Гетьмана» 2011-2021 pp.

Не зважаючи на кардинально протилежні результати дослідження сформованості ментальних навичок півкуль головного мозку, показник збалансованої модальності протягом десятиліття залишається майже на одному рівні - приблизно 30\%, що дозволяє конкретизувати перше стратегічне завдання в аспекті необхідності забезпечення формування саме збалансованої модальності мислення здобувачів як здатності ефективно використовувати ментальні навички обох півкуль головного мозку, що вимагатиме змістовних змін у методичній діяльності викладачів у напрямі розробки, апробації та імплементації ефективного методичного інструментарію у практику викладання навчальних дисциплін.

Таким чином, тактично, враховуючи рівні сформованості ментальних навичок здобувачів, протягом 2019-2021 pр., крім методів активного навчання: дискусії, кейс-метод, розвивальні вправи, завдання різної складності, метод мозкового штурму, ігрові вправи, тренінги та проєкти, були запропоновані спеціально підібрані техніки і прийоми розвитку певного типу мислення, що 
були адаптовані авторкою до контенту навчальних дисциплін дидактикометодичного характеру [474, с. 112-113]:

$\checkmark$ для стимулювання розвитку логічного типу мислення - побудова ієрархій та послідовностей, «водна логіка» за Е. де Боно; елементи методик Е. де Боно, що стосуються підвищення продуктивності роботи мозку з фактичними даними, різного роду об’єктивною інформацією, наприклад, «6 капелюхів мислення» - у розділі прийомів мислення «у білому, чорному та жовтому капелюхах», або «6 пар взуття образу дії» - у розділі про «мислення та дії у сірих кросівках або коричневих черевиках»; створення конспект-схем (за методикою В.Ф. Шаталова);

$\checkmark$ для підтримки i стимулювання творчого мислення - методики нестандартного і творчого мислення за Е. де Боно, (наприклад, ефективний пошук альтернатив у процесі прийняття рішень, «латеральне мислення»), прийоми розвитку креативності мислення (наприклад, «бульбашки думок» М. Мікалко, «по-ідея» Е. де Боно, метод аналогій, випадкового слова та деякі інші);

для стимулювання розвитку збалансованої модальності та активізації застосування ментальних здібностей обох півкуль головного мозку - методика критичного мислення Д. Халперн та прийоми щодо розвитку критичного мислення інших авторів, наприклад оцінка стратегій роботи 3 партнером, методика розвитку радіантного мислення та створення інтелект-карт Т. та Б. Бьюзен, методики «шість капелюхів мислення» і «шість пар взуття образу дії» Е. де Боно, метод оцінки рішень «РМІ» та деякі інші.

Відповідні корективи довелося внести, враховуючи специфіку змішаного навчання поточного навчального року, тому більш активно використовувалися можливості платформи дистанційного навчання Moodle, cepвicy Zoom, за допомогою якого проводилися лекційні та частина практичних занять (особливо доречною була можливість створення окремих сесійних залів для виконання командних завдань), Telegram-канал для додаткових роз'яснень, рекомендацій та консультацій. 
Були запропоновані завдання більш аналітичного напряму, наприклад: дослідження ринку освітніх послуг України: суб'єкти, сегменти, ємкість; можливості співпраці академічних та корпоративних університетів (з участю у VIII Міжнародному бізнес-форумі «Наука-бізнес-освіта: стратегічне партнерство» 25.11.2020р., м. Київ). Також здобувачі виконували комплексне завдання «Ціна отримання кваліфікації «педагог професійного навчання» в українських ВНЗ». Їм пропонувалося проаналізувати дані щодо університетів в Україні, які здійснюють набір на спеціальність «Професійна освіта (Економіка)» та «Економічна та бізнес-освіта» (приклад наведений у таблиці 1).

Таблиця 1.

Ціна (контракт) та попит на отримання кваліфікації «педагог професійного навчання/фахівець з економіки» у 2020/2021 навчальному році

\begin{tabular}{|c|c|c|c|}
\hline Назва ВН3 & Спеціалізація & $\begin{array}{l}\text { Бакалаврат, } \\
\text { грн. на рік }\end{array}$ & $\begin{array}{c}\text { Кількість заяв / } \\
\text { Кількість } \\
\text { зарахованих } \\
\text { студентів }\end{array}$ \\
\hline $\begin{array}{l}\text { Національний педагогічний } \\
\text { університет імені } \\
\text { М.П.Драгоманова }\end{array}$ & $\begin{array}{c}\text { Професійна освіта } \\
\text { (Готельно- } \\
\text { ресторанна справа) }\end{array}$ & 14100 & $63 / 2$ \\
\hline $\begin{array}{l}\text { Національний педагогічний } \\
\text { університет імені } \\
\text { М.П.Драгоманова }\end{array}$ & $\begin{array}{l}\text { Професійна освіта } \\
\text { (Економіка) }\end{array}$ & 14100 & $20 / 0$ \\
\hline $\begin{array}{l}\text { Одеський національний } \\
\text { економічний університет }\end{array}$ & $\begin{array}{c}\text { Англійська мова в } \\
\text { економіці та бізнес- } \\
\text { освіті } \\
\end{array}$ & 18900 & $26 / 2$ \\
\hline $\begin{array}{l}\text { ДВНЗ «Київський національний } \\
\text { економічний університет ім. В. } \\
\text { Гетьмана» }\end{array}$ & $\begin{array}{l}\text { Економічна та } \\
\text { бізнес-освіта }\end{array}$ & 22800 & $100 / 11$ \\
\hline $\begin{array}{l}\text { Українська інженерно- } \\
\text { педагогічна академія }\end{array}$ & $\begin{array}{l}\text { Економічна та } \\
\text { бізнес-освіта }\end{array}$ & 14000 & $33 / 8$ \\
\hline $\begin{array}{l}\text { Чортківський навчально- } \\
\text { науковий інститут } \\
\text { підприємництва і бізнесу } \\
\text { Тернопільського національного } \\
\text { економічного університету }\end{array}$ & Професійна освіта & 17520 & $1 / 0$ \\
\hline $\begin{array}{l}\text { Мукачівський державний } \\
\text { університет }\end{array}$ & $\begin{array}{l}\text { Професійна освіта } \\
\text { (Економіка) }\end{array}$ & 13000 & $18 / 7$ \\
\hline $\begin{array}{l}\text { ДВНЗ "Херсонський державний } \\
\text { аграрний університет" }\end{array}$ & $\begin{array}{l}\text { Професійна освіта } \\
\text { (Економіка) }\end{array}$ & 12000 & $8 / 0$ \\
\hline
\end{tabular}


Необхідно було визначити: чому ціна отримання кваліфікації у різних закладах освіти $є$ різною?; з чого складається ціна отримання зазначеної кваліфікації; які фактори на це впливають та які з них є визначальними; запропонувати методику розрахунку собівартості надання освітніх послуг зі спеціальності «Професійна освіта», «Економічна та бізнес-освіта»; розробити елементи цінової політики університету; запропонувати шляхи стимулювання попиту абітурієнтів на дану спеціальність.

3 метою популяризації обраного фаху, підвищення практичної складової у підготовці здобувачів були проведені «workshop»и із залученням представника бізнесу - засновника та власника ТОВ «Свротелеком», доктора філософії у галузі державного управління, права П.Г. Булавіна, який також є активним учасником ринку корпоративної освіти. Крім того, здобувачі спеціальності «Економічна та бізнес-освіта» мали можливість (та скористалися нею) з метою забезпечення траєкторії індивідуального розвитку додатково обрати тренінг-курс «Розвиток економічного мислення», де під керівництвом авторки у тренінговому форматі формували й розвивали необхідні характеристики власного економічного мислення.

Протягом семестру аналізувалася динаміка прояву ментальних здібностей у власних портфоліо здобувачів та Контрольній таблиці розвитку економічного мислення, де фіксувалися результати виконання завдань, запропонованих для стимулювання ефективності та продуктивності останнього. Дієвість авторського підходу у визначенні методик, їх комбінації та вплив на риси економічного мислення підтверджується отриманими результатами, а також зростанням продуктивності інтелекту як здатності використовувати розум, щоб творчо відповідати на запитання та вирішувати практичні проблеми [475, с. 5]. В цілому, за начальний семестр відбулися суттєві покращення у роботі всіх десяти основних метальних навичках: числа, слова, логіка, переліки (списки), деталі (подробиці) - зафіксовано, що здобувачі почали більш точно формулювати визначення нових понять, встановлювати взаємозв'язки і підпорядкованість категорій та явищ, будувати послідовності, розраховувати показники 
економічної діяльності та прогнозувати вплив факторів зовнішнього та внутрішнього середовища; зображення, уява, колір, ритм, простір - здобувачі більш активно почали застосовувати кольори та ритм, навіть під час навчання іншим дисциплінам, впроваджувати візуалізації ідей i нових понять, застосовувати асоціативні зображення, системні (узагальнюючі) образи економічної та педагогічної діяльності, бізнес-процесів; продукувати більшу кількість ідей в процесі вирішення задач. До того ж, наприкінці навчання були зафіксовані позитивні зміни у рівні розвитку соціального інтелекту, дослідження якого проводилося за методикою Дж. Гілфорда $[473$, с. 100] (переважна більшість здобувачів показали середній та вище середнього рівні) та у рівні професійної спрямованості (визначався за методикою Т.Д. Дубовицької [473, c. 145]), де були отримані високі показники у 82,1\% респондентів. Така позитивна динаміка відобразилася і в успішності навчання здобувачів (показник склав 95,6\%), а частка найвищих оцінок «відмінно» А становила 28,8\%.

Отже, педагоги в сучасному освітньому просторі у рамках методичної діяльності здатні вирішувати окреслені стратегічні і тактичні завдання з метою формування професійної компетентності здобувачів освіти:

1. визначити компоненти професійної та соціальної компетентності здобувачів з кожної навчальної дисципліни (з врахуванням тенденцій світового ринку праці та запитів роботодавців);

2. відібрати, апробувати та імплементувати методичні інструменти (методи, форми, прийоми, техніки, засоби навчання) у навчальний процес 3 метою формування визначених компетентностей та їх подальшого розвитку протягом всього життя;

3. забезпечити ефективність навчання здобувачів з кожної навчальної дисципліни шляхом комбінації різних методичних інструментів.

Продукування системою освіти нових педагогів інноваційного типу, здатних не просто до самовдосконалення, а й на адаптацію нового до стану засвоєння іншими, дасть можливість суспільству адекватно відповідати на виклики майбутнього; скоротити час, необхідний на засвоєння нових знань, 
умінь і навичок; значно скоротити розрив між науковою фантастикою та реальністю. У дослідженні консалтингового агентства Capgemini освіта буде залишатися у ТОП-10 галузей, де працюватиме найбільша кількість мільйонерів, оскільки, у міру того як росте багатство, все більше людей прагнуть здобувати освіту, яка дозволяє підвищити багатство [476]. Саме педагогі здатні здійснювати суттєвий вплив на формування особистісного потенціалу майбутнього фахівця, центральним компонентом якого є навички мислення та комерційний інтелект - другої, на наш погляд, найважливішої інтегральної властивості особистості, особливо, коли її діяльність пов'язана з економікою. I якщо стратегічно жодних сумнівів не виникає, то тактично є неймовірно широке коло завдань, вирішення яких буде залежати від компетентності самого педагога, його особистих уподобань та віри в ефективність власної методичної системи. 